Article

\title{
Intercultural Responsiveness: Learning Languages Other Than English and Developing Intercultural Communication Competence
}

\author{
Ping Yang \\ School of Humanities and Communication Arts, Western Sydney University, Locked Bag 1797, \\ Penrith, NSW 2751, Australia; p.yang@westernsydney.edu.au
}

Received: 25 April 2020; Accepted: 28 May 2020; Published: 2 June 2020

\begin{abstract}
This paper conceptually discusses why it is essential to foster intercultural responsiveness through learning a language other than English (LOTE) and developing intercultural communication competence at Australian universities. Learning a LOTE is meaningful and helps second language learners develop social skills and cognitive competence, understand the linguistic system of the LOTEs, and sense differences between their home language/culture and target language/culture, and then pave the way to developing intercultural communication competence. However, a LOTE as a compulsory unit has little presence in Australian university curricula. No Australian universities require that students need to learn a LOTE to meet the course requirements. Learning a LOTE is conducive to both bilingual/multilingual and intercultural communication competence development. Furthermore, most current work studies intercultural verbal communication competence more than intercultural nonverbal communication competence. While intercultural verbal communication is audio-oriented, voiced, and externalized with open messages, intercultural nonverbal communication is visually oriented, silent, and internalized with hidden cues. Only when both components are considered can people achieve effective intercultural communication. The implications for learning a LOTE and developing intercultural communication competence are discussed.
\end{abstract}

Keywords: language other than English (LOTE); second language learning; intercultural responsiveness; intercultural communication competence; higher education

\section{Introduction}

Foreign/second language learning is becoming more and more popular as the world is becoming increasingly globalized and intercultural communication is intensified as a result of global business and the internationalization of education. As the English language has been used as an international language, it is due to the university course requirements that the students in many non-English-background countries learn English as a foreign language (EFL). For example, Chinese ${ }^{1} /$ Japanese students studying higher education courses (e.g., bachelor's degree, master's degree, or doctoral degree) at any Chinese/Japanese universities are required to take the English language as a core unit. The Chinese university students must pass the nationwide College English Test (CET-4) ${ }^{2}$ before they can graduate with the fulfilment of the academic degrees, and some of them can pass CET-6,

1 The word Chinese is used here as an umbrella term that refers to native speakers of Mandarin, Cantonese, and other local languages or dialects used in mainland China.

2 CET-4 and CET-6 are designed to test English language communication skills and the proficiency of Chinese university students who do not study the English language as their major. Those who study the English language as their major are required to take the Test for English Majors (TEM-4 and TEM-8) (Guo 2016; Guo and Chen 2007; Zhou 2004). 
whose level is higher than that of CET-4. Furthermore, those who study the English language as their major are not only required to pass the Test for English Majors (TEM-4), with TEM-8 as optional but also need to take a second foreign language. Although Chinese university graduates generally achieve reasonable English language proficiency in listening, speaking, reading, writing, and translation (Chinese to English), many of them have some room to improve their communication skills (Gu 2018). Many universities in the United States also require that their students take a foreign language. For example, students studying at the State University of New York (SUNY) are required to learn a foreign language to meet the course requirements. However, as no standardized tests at the national level are used to measure the foreign language fluency of American university students, it is not known what level of proficiency they achieve after they complete the foreign language unit. It is a positive move that more and more native English speaking students are becoming highly motivated in learning a second language and are developing their bilingual skills (Duff 2017) and intercultural communication competence through various ways, such as interacting with the other language speakers in a second language, studying a language other than English (LOTE) unit or course, and participating in study abroad and international mobility programs. The Australian Government has gained an insight into the future sustainable development of the nation and released the ambitious white paper Australia in the Asian Century in 2012 and launched the New Colombo Plan in 2013. These initiatives have been put in place to support Australian students in their short-term or semester/year-long overseas study and to experience the target language and cultural immersion. However, many Australian students are hardly interested in doing so, as they have not become aware of, or may not fully understand, the long-term benefits of learning a foreign/second language for their future. Djite (1994, p. 156) points out the "worrying sign" that many Australian university staff do not have an attitude to a LOTE and students do not want to have a LOTE in their study program. How can Australian students benefit from learning a second language and developing intercultural communication competence? In what way can second language learning and the development of intercultural communication competence contribute to intercultural responsiveness? Why are second language education and intercultural responsiveness important for Australian universities?

This paper aims to explore how second language education and intercultural communication competence work together to bring intercultural responsiveness into reality in the Australian higher education sector. First, I review the relevant literature, discuss the benefits Australian students can gain from learning a second language and developing intercultural communication competence, then examine how second language learning and the development of intercultural communication competence contribute to intercultural responsiveness, and finally highlight the importance of second language education and intercultural responsiveness for the internationalization and sustainable development of Australian universities.

\section{Literature Review}

This section focuses on how learning a foreign/second language can help language learners achieve in the process of language learning from the perspectives of cognitive skills development, social skills development, and emotional development. Additionally, intercultural communication competence is reviewed to foreground the logical link between the basics of language learning and its use in the target socio-cultural context.

To discuss language learning as a foundation for understanding cultural elements, Sharifian (2017) stated the following in his theoretical framework of cultural linguistics.

As a central aspect of cultural cognition, language serves ... , as a 'collective memory bank' of the cultural cognition of a speech community. Many aspects of language are shaped by elements of cultural cognition that have prevailed at different stages in the history of a speech community. In other words, these elements can leave traces in subsequent linguistic practice. In this sense, language can be viewed as a primary mechanism for 'storing' and communicating cultural cognition, acting both as a memory bank and a fluid vehicle for the (re-)transmission of cultural cognition. (p. 2). 
A language conveys one's inner thinking, cultural values, and social behaviours, and is used as a communicative tool to exchange ideas with people from the same, as well as different, cultural backgrounds. Furthermore, foreign/second language learning is related to intercultural communication competence development, and both are key to the intercultural responsiveness essential to culturally diverse Australian universities.

\subsection{Learning an Additional Language}

There are many benefits in learning a LOTE and it can be done in varied and meaningful ways. As far as the benefits of LOTE learning are concerned, many research publications have shown that it can benefit learners in their cognitive development (Stafford 2013), emotional development (Swain 2013), intercultural communication skills (Sharifian 2007), and verbal/nonverbal communication competence across cultures (McCafferty 2004).

First, learning a LOTE helps open a wide window through which to view and approach different things, and connect people with interests. It creates an opportunity for LOTE learners to develop their cognitive ability to recognize different language families, for example, English as an Indo-European language family member (Baldi 2008) and Chinese as a Sino-Tibetan language family member (Handel 2008). As English speakers learn Chinese as a foreign/second language, they come to know that there are similarities and differences between the two languages. Their Chinese language learning experience can also equip them with the growing capacity to observe and analyze the language differences in terms of pronunciation, vocabulary, and grammar. It is meaningful to learn the semantic-cultural differences between two languages at the lexical level. Take the English 'individualism' and the Chinese “个人主义” (individualism), for example, many resource books (e.g., Chinese dictionaries) regard them as translation equivalents. However, a careful comparison of the two shows that they are different in their connotation and are culturally inequivalent (Yang 2011). Therefore, it is proposed that “个体主义” (individualism) be used instead because it has some elements, such as self-reliance and adventure-taking in starting one's own business, similar to individualism, though not all. It is the same case with the English 'union' and Chinese “工会” (worker union). While the former largely works against the government (e.g., federal or state) and institutions (e.g., companies or universities) to protect union members' interests and rights, the latter most often works with the government and authorities to look after employees and de-escalate the situation. It is also useful to note the grammatical differences between the languages. For instance, there are no articles (e.g., a, an, the) in Chinese (nor in Japanese, Thai, and Vietnamese) as there are in English. This knowledge is particularly important for EFL/ESL (English As a Second Language) teachers who have bilingual or multilingual skills and they can assist their students in learning articles to the point by showing the grammatical differences. When they are aware of these, they are likely to know what challenges some of the students (e.g., Asian language speakers such as Chinese, Japanese, Thai, and Vietnamese) have and then what to focus on in teaching grammar. Such bilingual knowledge and skills help the teacher identify where the students have difficulties and make errors due to first language interference. Furthermore, it can help the teacher to guide the students to build connections between English grammar (e.g., an indefinite article "an") and pronunciation (e.g., vowel letters and sounds) and learn them thoughtfully (Yang 2014). These integrative skills-based and learner-centred teaching and learning styles are particularly productive for intermediate and advanced EFL/ESL learners (Brown 2015; Harmer 2015). Learning a LOTE enables monolingual English speakers to recognize language differences and to analyze them critically, thus not only increasing their linguistic competence but also helping to grow their pragmatic competence in using the foreign/second language appropriately in a given socio-cultural context.

Second, LOTE learners are equipped with more language resources to manage intercultural differences and are more likely to succeed in developing their emotional and social skills, as well as intercultural communication competence. Learning a foreign/second language can help make it possible for them to understand and appreciate a foreign/second culture, which is closely related to the language roots and connections. Taking the word "dragon" for example, an English speaker 
learning Chinese as a foreign/second language is quick to understand its metaphoric meaning and its associated phrases, like "a dragon child" (a promising child) favoured by Chinese nationals, despite the unpopular image "dragon" conjures up in the English language and culture. Similarly, an English speaker learning Japanese as a foreign/second language would find it less difficult to perceive why deep thinking and minimum speech, if not silence, are generally respected in Japanese culture and society (Jones 2011; Morsbach 1988). This is significant for native English language speakers, as this helps enhance their emotional development of language and culture. The use of first/second person pronouns generally demonstrates the user's cultural orientation. Speakers from the individualist culture tend to use first-person singular pronouns, whereas those from the collectivistic culture prefer to use the second-person plural (Na and Choi 2009). The use of first-person pronouns also demonstrates the user's emotional status. For instance, take the Chinese first-person singular and second-person plural. They are used to express self-depreciation (e.g., 小弟/妹, little brother/sister) and other-appreciation (大哥/姐, big brother/sister) regarding mutual status, gender, and age factors, and the address terms are even more complicated for socio-cultural politeness and pragmatic appropriateness in the classical Chinese language (Yang 2011). Thus, foreign/second language learning leads to a sense of inter-language connections and appropriate intercultural interaction. Equipped with the foreign/second language-relevant cultural knowledge, English language speakers would be able to confidently and competently communicate with people from diverse language and cultural backgrounds, thus leading to a mutual understanding, despite language and cultural differences.

\subsection{Intercultural Communication Competence}

Intercultural communication competence includes intercultural verbal communication competence and intercultural nonverbal communication competence. Intercultural verbal communication competence is concerned with the sufficient language-related knowledge, skills, and appropriate culture-sensitive attitudes a person needs to have in successful and effective intercultural verbal communication, while intercultural nonverbal communication competence is concerned with the sufficient knowledge, skills, and appropriate culture-sensitive attitudes related to nonverbal communication a person needs to have to achieve successful and effective intercultural verbal communication in language education sectors (Yang 2018a). Piller (2017) insists that education practitioners and teachers in Australia need to develop their intercultural communication competence, as they interact with students from diverse cultural backgrounds, particularly international students who may communicate verbally and nonverbally in different ways from what is considered "normal" by local speakers, and further linguistic and cultural diversity helps keep Australian educational systems socially sustainable.

Intercultural verbal communication competence has been extensively studied and many research outcomes have been published. Japanese university students find that because there are many language differences and communication pattern variations between Japanese and other languages, they have come across many intercultural communication challenges and learnt from failures (Nishida 1985). There are many issues related to intercultural verbal communication competence and international students, for example, managing intercultural communication stress (Redmond and Bunyi 1993), and understanding the various issues international Chinese students have while studying at a New Zealand university (Holmes 2006). Additionally, university staff members also need to have intercultural communication competence to meet with students' learning needs (McCalman 2014).

In recent years, intercultural nonverbal communication competence has also received more attention than before. For example, Redmond (2000, p. 151) "investigated the effects of cultural distance on the amount of stress, the handling of stress, and intercultural communication competence as reported by international students attending a US university". As the number of international students is increasing, and as they come from different language and cultural backgrounds, Australian university staff members need to think deeply and seriously about how to provide quality general services and academic learning advice and support, and the important thing is whether they are willing 
to develop their intercultural nonverbal communication skills and whether the universities support or provide relevant training (Yang 2015a, 2017, 2018a).

International education in Australia is a profit-making business that creates jobs and revenue income with few environmental issues. But the questions remain as to whether Australian universities meet the benchmark criteria and provide a good education and associated services to international students as they advertise and promise. Moran et al. (2011) studied how global leadership strategies can be used to effectively manage cultural differences in cross-cultural business success. Jackson (2015) calls for English-speaking universities to take actions for their staff to undertake intercultural communication training to become more physically, psychologically, and emotionally intercultural.

\section{Research Questions}

Learning a foreign/second language and developing intercultural communication competence is essential to Australian universities. The following three research questions are proposed:

a. What benefits does LOTE learning bring to Australian university students?

b. Why is intercultural communication competence development essential to Australian universities?

c. What do LOTE learning and intercultural communication competence development mean to the internationalization of Australian universities?

As Australian university students are not required to learn any foreign/second language as a compulsory part of their courses while they are studying at universities, they may not realise the resources readily available that can help boost their foreign/second language levels and intercultural communication competence, as well as increase their career opportunities in the future. This underlies the motivation to look at the above research questions.

\subsection{Intercultural Responsiveness Is Essential to Australian Universities}

Australia is a multilingual and multicultural nation, where many communities and family members come from diverse language and cultural backgrounds, thus speaking different languages and sharing diverse cultures. Every single country around the world was represented in Australia's population in 2018 and the proportion of Australia's population born overseas was $29.4 \%$ in the same year (Australian Bureau of Statistics 2018). Furthermore, international education plays a key role in promoting Australian language and culture and consolidating the Australian economy in the global race. To maintain Australian cultural diversity and make Australian international education sustainable, Australian higher education providers and university communities are aware of the essential role intercultural responsiveness plays in making intercultural communication ready on the university campus and in the classroom (Velliaris and Pierce 2017; Alexander and Dooey 2017; Yang 2017). But the issue is that intercultural interaction without essential intercultural communication competence may not lead to intercultural understanding for many reasons. One of the reasons is that the monolingual speakers in intercultural interactions do not have or have insufficient foreign/second language literacy, suggesting an absence of language equity and the presence of linguistic imperialism (Yano 1998). There were incidents in which a few school deans of a given university advised their non-native English speaking staff who taught translation courses not to use the target language, but English only, in the workplace. They seemed to be unaware that teaching translation cannot happen without using both English as a source language and other languages as target languages, and vice versa. This has implications for the Australian university language policy and language curricula, as well as why a LOTE is not currently required in any Australian university courses. This discussion centres on the need for Australian university students to learn a foreign/second language and develop their intercultural communication competence. 


\subsection{Additional Language, Extra-Linguistic Capital and Power}

It is worth the attention of monolingual (English) speakers studying at Australian universities to realise that learning a LOTE is more than acquiring additional language skills or extra knowledge about another language. Learning a LOTE can help Australian university students develop their cognitive competence and socio-affective competence ( $\mathrm{Ng}$ and Wigglesworth 2007), which are important in effective and successful intercultural communication. A LOTE enables the monolingual Australian university students to gain language capital, provide them with extra opportunities to compete on international job markets or land their future jobs in regions with booming economies or their preferred destinations.

As LOTE learners, Australian university students have an opportunity to develop their cognitive competence that can facilitate their intercultural communication with people who speak a LOTE. With LOTE knowledge and background information in mind, monolingual (English) Australian university students are likely to make sense of the social practices and cultural values of other people because they help construct meaning. For example, "white" is generally perceived to have a negative sense in China and negative meaning when collocated with another word. This is seen in some Chinese phrases such as “白色恐怖” (white terror) and “白事” (funeral). The association of the perception of colour schemes with the construction of cultural connotations helps the LOTE learners gain a deep understanding of intercultural differences, as observed in Chinese and English lexicons. It best explains that what is considered as verbally normal and acceptable in one language and culture may be regarded as just the opposite, thus highlighting the socio-cultural context of which they need to become aware when using the relevant words. For another example, while expressions such as "an ambitious musician" and "an ambitious terrorist" are used and accepted in English culture, explicitly different lexicons, a complimentary wording “有雄心的音乐家” (an ambitious musician) and a derogatory wording “有野心的恐怖分子” (an ambitious terrorist) are used in Chinese. It is interesting to note that "ambition" has both complimentary and derogatory meanings in one English word, whereas its two Chinese translation equivalents do not share the complimentary “雄心的” and derogatory “野心的” semantically opposite meanings in one word, but use two different words (Yang 2012). This is not a single case and there is a list of similar examples. Such critical analysis of the major languages helps LOTE learners understand that a single English word may have a different meaning pair in another language, such as Chinese. What is more, the awareness of language differences provides LOTE learners with lexical resources necessary for meaningful sentence construction and text development. This linguistic competence development helps LOTE learners improve their socio-cultural competence and pragmatic competence in using the target language appropriately and mingling with the target culture successfully (Yang 2018b). It eventually leads to intercultural communication competence development and language capital that is essential to their understanding of other cultures before potential cultural adaptation occurs and grows when Australian students study overseas. This can be seen in the importance of intercultural communication and multicultural nonverbal communication designed and delivered at some universities, where they take these units in tandem with LOTE units and learn to theorize everyday experiences and events, taking into consideration cultural diversity, and reflecting on them critically. Through online discussion, group work, and individual/pair presentation, they start to see their intercultural verbal/nonverbal communication competence emerge. Yang (2018c) states that Australian students undertaking study abroad programs find that learning Mandarin in social interactions (e.g., bargain shopping, homestay) is more effective and engaging than in the classroom only and they also see and hear ordinary Mandarin speakers from different places and find themselves immersed in the diverse cultural context. Similarly, Nerlich et al. (2018) also find that Australian students studying in China have both varied in-country experiences with their language learning and cultural immersion, with some feeling more positive than others.

It is found that cross-cultural pairing influenced mentors' intercultural understandings, enabled cross-cultural relationships to develop, and provided opportunities for students to interact with people of other cultures and religions. Mentors changed their views of others-of immigrants, of refugees, 
and also of Anglo-Australians. They experienced increased personalized understanding or gained a widened perspective of their mentees, who were of cultures different from their own. Mentors stated that over time their interactions evolved into either a mutually rewarding friendship or a comfortable relationship within a learning community that valued collective learning. It is proposed that increased intercultural understanding emerges from an increased emphasis on the creation of meaningful, transactional relationships among culturally diverse students within a supportive academic environment.

The stakeholders, including international students, of the Australian university community, are of multilingual and multicultural backgrounds. The cultural diversities can be seen even in English-background cultures and non-English-background cultures. The former includes Australian culture, American culture, British culture, Canadian culture, and New Zealand culture, while the latter includes a wide range of different cultures, such as Indian culture, Chinese culture, Japanese culture, and so on. They help make Australian universities viable and vigorous and it is hard to imagine their sustainable development without such cultural diversity.

\subsection{Developing Intercultural Communication Competence and Keeping Australian Universities Sustainable}

Intercultural communication competence refers to a person's capacity and skills in communicating with people from other cultures successfully and effectively (Jackson 2014). Intercultural communication competence development is built on a person's LOTE competence development and socio-cultural pragmatic competence development in a culture other than English (COTE). As Australian universities are part of Australian multilingual and multicultural communities, socio-cultural pragmatic competence development in COTEs is essential to the sustainable growth and development of Australian universities. While the former is a fundamental base, the latter is the upper part of that foundation, and the two are interlocked and they support each other.

Why is there a need to emphasize and respect COTEs when speaking English as a working language for communication purposes and living in Australia? Australia is a democratic country where each individual has equal rights and is treated equally. This would include the home language and home culture of the adult migrants living in Australia. Australian multilingual and multicultural communities provide a good platform, where the Australian university community should lose no time in developing its members' socio-cultural pragmatic competence in COTEs. The current situation is that people from other cultural backgrounds are more familiar with English culture, while those of an English background are less familiar with other cultures in Australia. When the unfamiliarity persists, intercultural communication can readily fail, misunderstanding can occur, and issues, such as a lack of social harmony and unrest, can emerge because of indifference to other cultures.

What happened in American and Australian history and recently to some European countries (e.g., anti-immigrant policy and racial discrimination) are good lessons to learn. Santa Ana (1999) analyzes the public discourse using the animal metaphor to show their dislike for the immigrants who have made up the majority of the United States. Similarly, Marlow (2015) studies "the multilingual Coca-Cola 'It's Beautiful' commercial" aired in the US and penetratingly shows how the American Dream was used to discriminate against the new arrivals. In Australia, the White Australia policy was designed to discriminate against people of non-white or non-European backgrounds, particularly Japanese and Chinese. Pauline Hanson's One Nation party openly showed a dislike of Asian immigrants in the late 1990s and has recently spoken against Muslim immigrants. She ridiculed Muslim females by mimicking their dress style in the Senate, showing disrespect for their cultural observation. Following France, she called for an immediate ban on Muslim immigrants and on wearing a hijab in public. In Europe, the current collective dispels the arriving immigrants and refugees from other countries and persistent discrimination against those of immigrant backgrounds or "trouble-makers" is not a new idea, and it happened in European history and has a record (Mols and Jetten 2014).

Intercultural communication competence of the Australian university community is even more useful in supporting students of refugee backgrounds while they are doing coursework or pursuing 
higher degree research projects. Yang (2015b) thinks that Australian university teachers will find it helpful if they apply the language teaching principles (see cognitive principles, socio-affective principles, and linguistic principles by Brown (2015)) when assisting adult refugee learners in learning English as a second language. Using the socio-affective principles, the teachers understand the role of intercultural communication knowledge, deploy their intercultural communication skills, and take on a culture-appropriate attitude when working with the adult refugee learners, thus building socio-cultural bonding with them and making their learning collaborative and stress-free. In another project, Yang (2015c) finds that the student teachers' intercultural communication competence development can help achieve effective ESL teaching and provide learning support to adult refugee students through TESOL (Teaching English to Speakers of Other Languages) service-learning activities. Vickers et al. (2017) look at an effective approach to supporting refugee student learning through "cross-cultural pairing" (p. 198) and the mentor-mentee working relationship, which lead to positive outcomes with mutual trust built and increased inter-personal understanding.

\subsection{Internationalizing Australian Universities through LOTE Learning and COTE Development}

"In a global economy, internationalisation of higher education is understood here as both the concept and the process of integrating an international dimension into the teaching, research and service functions. As this concept becomes more widely understood and the process of internationalisation matures, it is increasingly urgent that institutions of higher education address the issues of quality assessment and assurance of the international aspects of their operations" (Organisation for Economic Co-Operation Development 1999, p. 3). Although Australian universities are lucky to have some inheritable advantages and qualities, including the international composition of their stakeholders and a strong motivation to engage with other international counterparts for program articulations and cross-institutional collaborative research projects, "the process of integrating an international dimension" (ibid.) into the Australian universities is not simple and requires many efforts because of intercultural differences and challenges. There is a need to realise that LOTE learning and attitudes towards COTEs development need much support and action.

The stakeholders of Australian universities come from diverse language and cultural backgrounds. Australian university staff members (e.g., management, academic staff, and professional staff) and students (e.g., local and international) speak different languages and have different social practices (e.g., Christmas, Chinese New Year, Ramadan), religious beliefs (Christian, Catholic, Muslim, etc.), and cultural values (e.g., individualism vs. collectivism). It is these language and cultural diversities that makes the Australian university communities unique and gives them much potential for international engagement and partnership. The language and cultural diversities have created a platform where LOTE learning and COTE development are made possible. They function as a bridge that links teaching, research, and service function activities between Australian universities and international partner universities. To provide (international and local) students with intercultural communication competence in their university education, international education providers have the responsibility to contribute to their intercultural communication competence so that they have an opportunity to become interculturally competent (Jackson 2015).

\section{Solutions and Recommendations}

To discuss solutions and seek recommendations to address LOTE learning and COTE development, I focus on two key areas. One is about how LOTE learning can be facilitated through using Internet-based technology and the other is about EFL/ESL learning and cultural immersion in context.

\subsection{Technology-Facilitated LOTE Learning}

In the 21st century, digital technology is transforming how foreign/second language learning can be accessed in multiple and flexible modes. First, blended learning can meet individual student learning needs. While a LOTE is learnt through teacher instructions in a traditional classroom environment, it 
can be enabled and enriched with such technologies as iPhones and iPads, that are likely to engage students in various learning activities. Aarts et al. (2012) find that smartphones can be used to facilitate their learning of grammar knowledge and that their students learn it with fun and success. Second, there is no doubt that a language can be effectively learnt in technology-enriched social media, modular object-oriented dynamic learning environment (MOODLE) (Uzun 2012), machine-driven devices (Myers 2000), and video-enabled online interactive meetings (Pasfield-Neofitou 2012), as well as face-to-face, since more and more international students study overseas and people travel and work in the destination countries. Zoom, Microsoft Teams, Canvas, and so on are being used for online teaching/learning and meeting purposes to maintain social distancing because of the recent COVID-19 epidemic. As the National Broadband Network continues to upgrade itself and cover Australian metropolitan and regional areas, Australian university students will find online learning beneficial in many ways, though challenging at the same time. These recent technologies make it easy for foreign/second language learners to get in touch with the people who speak the target language they are interested in learning and the target culture they want to understand (Salaberry 2001). They help make the virtual learning of LOTEs and COTEs possible, connect people from afar, shorten social distancing, and broaden student worldviews. In summary, technology-assisted LOTE learning can motivate Australian students to further approach COTE learning with much curiosity and interest at any time and in any place.

\subsection{Language Learning and Cultural Immersion}

To encourage Australian students to become Asia-literate through learning the major Asian languages, such as Chinese and Japanese, and to understand Chinese and Japanese cultures, the Australian Government has had the white paper Australia in the Asian Century in place and has launched two initiatives, the Endeavour Mobility Grant and the New Colombo Plan. Some Australian undergraduate and postgraduate students have successfully applied for the grants and participated in study abroad programs for short-term or full-semester study.

More and more relevant research reports on Australian student language learning and cultural immersion have been published. Steve (2016) uses various data sources to show more and more Australian students are studying abroad either get a full degree or "accrue credit towards a degree that will be awarded back in their home country" (p. 40). Tracey et al. (2016) focus on pre-departure training and administrative support for Australian students on a study-abroad program so that they are ready for intercultural learning. Townsin and Walsh (2016) find that Australian students can positively transform themselves and become interculturally competent through mobility programs, and this can happen when they engage in various activities, communicate with people of different cultural backgrounds, and learn from errors and trials. Yang (2016) insists that study abroad and mobility programs stand to provide Australian students with many opportunities to learn a functional language, improve communication skills, and immerse them in the target culture. In another project, Yang (2018b) examines data of various kinds (e.g., written, video, YouTube clips, radio broadcast) and exemplifies how international students from Australia, France, the UK, and the US learn Mandarin Chinese by all means (e.g., attending classes, talking with people, learning on the job, teaching English), maximize their cultural immersion, and develop their intercultural communication competence. Yang (2018c) critically analyzes international students' intercultural adaptation and growth experiences in China, examines how they maximize their intercultural interactions and improve their language skills effectively, and looks at how they foster a positive attitude toward China and achieve successful intercultural awareness.

\section{Conclusions}

This paper highlights the claim that learning a LOTE and developing intercultural communication competence and intercultural responsiveness is essential to Australian university development and international education sustainability and will be for many years to come. This importance can be seen 
in the Australian Government's strategies and investment in study-abroad and mobility programs (e.g., New Colombo Plan) for the Australian universities' long-term future.

There are many urgent issues in teaching, research, and service functions that need timely communication and collective solutions from Australian universities and their international counterparts. For example, whether the Australian university curricula could be considered international and to what extent they could be considered as such remains little known. International curricula are characteristic of the values of open-mindedness, inclusion, respect, and tolerance that facilitate cross-institutional program articulation and development (Sherlock 2002). International curricula should include intercultural communication competence, as it involves intercultural knowledge, skills, and culture-appropriate attitudes that foster intercultural responsiveness to collaboration between all parties. Sample (2013) has shown that students who completed study-abroad programs and pre-departure training have higher intercultural competence than those who have not done so. However, many tasks are ahead as to what specific intercultural communication competence elements Australian universities need to include in their internationalization curricula, how they are designed, developed, and delivered, as well as how they are assessed and evaluated. While this paper focuses on the current situation of LOTE and intercultural communication competence at Australian universities and calls upon them to reflect on these issues and take action to keep their future development sustainable, the discussion is also applicable to universities in many other countries where these issues need reflections and actions.

Funding: This research received no external funding.

Acknowledgments: I thank the Languages editorial office for inviting me to contribute this paper. I also thank the two masked reviewers for their constructive comments.

Conflicts of Interest: The author declares no conflict of interest.

\section{References}

Aarts, Bas, Dan Clayton, and Sean Wallis. 2012. Bridging the grammar gap: Teaching English grammar to the iPhone generation. English Today 28: 3-8. [CrossRef]

Alexander, Paul R., and Patricia M. Dooey. 2017. English language interventions that improve international business student group-work performance. In Intercultural Responsiveness in the Second Language Learning Classroom. Edited by Jones Kathryn and Jason R. Mixon. Hershey: IGI Global, pp. 202-21.

Australian Bureau of Statistics. 2018. Australia's Population by Country of Birth. Available online: https://www. abs.gov. au/ausstats/abs@.nsf/Latestproducts/3412.0Main\%20Features22017-18?opendocument\&tabname= Summary\& prodno $=3412.0 \&$ issue $=2017-18 \&$ num $=\& v i e w=($ accessed on 19 June 2019).

Baldi, Philip. 2008. English as an Indo-European language. In A Companion to the History of the English Language. Edited by Haruko Momma and Michael Matto. Malden: Blackwell Publishing Ltd., pp. 127-41.

Heekyeong, Lee. 2015. Teaching by Principles: An Interactive Approach to Language Pedagogy, 4th ed. Heekyeong, Lee. White Plains: Pearson Education.

Djité, Paulin G. 1994. From Language Policy to Language Planning: An Overview of Languages Other Than English in Australian Education. Canberra: National Languages and Literacy Institute of Australia.

Duff, Patricia A. 2017. Commentary: Motivation for learning languages other than English in an English-dominant world. The Modern Language Journal 101: 597-607. [CrossRef]

Gu, Mini. 2018. An Introduction to China's College English Test (CET). Available online: https://wenr.wes.org/ 2018/08/an-introduction-to-chinas-college-english-test-cet (accessed on 16 May 2020).

Guo, Yan. 2016. The impact of the market economy on English teachers. In Spotlight on China: Changes in Education under China's Market Economy. Edited by Shibao Guo and Yan Guo. Rotterdam: Sense Publishers, pp. 119-36.

Guo, Linghui, and Yanfen Chen. 2007. A comparative study of CET-4 and TEM-4 in China. Asian Englishes 10: 90-102. [CrossRef]

Handel, Zev. 2008. What is Sino-Tibetan? Snapshot of a field and a language family in flux. Language and Linguistics Compass 2: 422-41. [CrossRef]

Harmer, Jeremy. 2015. The Practice of English Language Teaching, 5th ed. Harlow: Pearson Education. 
Holmes, Prue. 2006. Problematising intercultural communication competence in the pluricultural classroom: Chinese students in a New Zealand university. Language and Intercultural Communication 6: 18-34. [CrossRef] Jackson, Jane. 2014. Introducing Language and Intercultural Communication. New York: Routledge.

Jackson, Jane. 2015. Becoming interculturally competent: Theory to practice in international education. International Journal of Intercultural Relations 48: 91-107. [CrossRef]

Jones, Sally. 2011. Speech is silver, silence is golden: The cultural importance of silence in Japan. The ANU Undergraduate Research Journal 3: 17-27. [CrossRef]

Marlow, Mikaela L. 2015. The American Dream? Anti-immigrant discourse bubbling up from the Coca-Cola 'It's Beautiful' advertisement. Discourse E Communication 9: 625-41.

McCafferty, Steven G. 2004. Space for cognition: Gesture and second language learning. International Journal of Applied Linguistics 14: 148-65. [CrossRef]

McCalman, Claudia L. 2014. International instructor preparing teachers for multicultural classrooms in the United States: Teaching intercultural communication competence online. New Directions for Teaching and Learning 138: 73-81. [CrossRef]

Mols, Frank, and Jolanda Jetten. 2014. No guts, no glory: How framing the collective past paves the way for anti-immigrant sentiments. International Journal of Intercultural Relations 43: 74-86. [CrossRef]

Moran, Robert T., Philip Robert Harris, and Sarah Virgilia Moran. 2011. Managing Cultural Differences: Global Leadership Strategies for Cross-Cultural Business Success, 8th ed. Oxford: Butterworth-Heinemann.

Morsbach, Helmut. 1988. The importance of silence and stillness in Japanese nonverbal communication: A cross-cultural approach. In Cross-Cultural Perspectives in Nonverbal Communication. Edited by Fernando Poyatos. Lewiston: C. J. Hogrefe Inc., pp. 201-15.

Myers, Marie J. 2000. Voice recognition software and a hand-held translation machine for second-language learning. Computer Assisted Language Learning 13: 29-41. [CrossRef]

$\mathrm{Na}$, Jinkyung, and Incheol Choi. 2009. Culture and first-person pronouns. Personality E Social Psychology Bulletin 35: 1492-99.

Nerlich, Steve, Ross Tan, Donna Velliaris, Ping Yu, and Christopher Lawson. 2018. Australian students in China: Making the foreign familiar. In International Students in China: Education, Student Life and Intercultural Encounters. Edited by Fred Dervin, Xiangyun Du and Anu Härkönen. Cham: Springer International Publishing, pp. 121-44.

Ng, Bee Chin, and Gillian Wigglesworth. 2007. Bilingualism: An Advanced Resource Book. New York: Routledge.

Nishida, Hiroko. 1985. Japanese intercultural communication competence and cross-cultural adjustment. International Journal of Intercultural Relations 9: 247-69. [CrossRef]

Organisation for Economic Co-Operation Development. 1999. Quality and Internationalisation in Higher Education. Edited by Co-Operation Organisation for Economic. Qualitâe et Internationalisation de L'enseignement Supâerieur. Paris: OECD Publishing.

Pasfield-Neofitou, Sarah E. 2012. Online Communication in a Second Language Social Interaction, Language Use, and Learning. Second Language Acquisition. Clevedon: Channel View Publications.

Piller, Ingrid. 2017. Intercultural Communication: A Critical Introduction, 2nd ed. Edinburgh: Edinburgh University Press.

Redmond, Mark V. 2000. Cultural distance as a mediating factor between stress and intercultural communication competence. International Journal of Intercultural Relations 24: 151-59. [CrossRef]

Redmond, Mark V., and Judith M. Bunyi. 1993. The relationship of intercultural communication competence with stress and the handling of stress as reported by international students. International Journal of Intercultural Relations 17: 235-54. [CrossRef]

Salaberry, M. Rafael. 2001. The use of technology for second language learning and teaching: A retrospective. The Modern Language Journal 85: 39-56. [CrossRef]

Sample, Susan G. 2013. Developing intercultural learners through the international curriculum. Journal of Studies in International Education 17: 554-72. [CrossRef]

Santa Ana, Otto. 1999. 'Like an animal I was treated': Anti-immigrant metaphor in US public discourse. Discourse E Society 10: 191-224.

Sharifian, Farzad. 2007. L1 cultural conceptualisations in L2 learning: The case of Persian-speaking learners of English. In Applied Cultural Linguistics: Implications for Second Language Learning and Intercultural Communication. Edited by Farzad Sharifian. Amsterdam: John Benjamins Publishing Company, pp. 33-52. 
Sharifian, Farzad. 2017. Cultural linguistics: The state of the art. In Advances in Cultural Linguistics. Edited by Farzad Sharifian. Singapore: Springer Singapore, pp. 1-28.

Sherlock, Patrick. 2002. Emotional intelligence in the international curriculum. Journal of Research in International Education 1: 139-58. [CrossRef]

Stafford, Catherine A. 2013. What's on your mind? How private speech mediates cognition during initial non-primary language learning. Applied Linguistics 34: 151-72. [CrossRef]

Steve, Nerlich. 2016. Counting outward mobility: The data sources and their constraints. In Handbook of Research on Study Abroad Programs and Outbound Mobility. Edited by Donna M. Velliaris and Deborah Coleman-George. Hershey: IGI Global, pp. 40-65.

Swain, Merrill. 2013. The inseparability of cognition and emotion in second language learning. Language Teaching 46: 195-207. [CrossRef]

Townsin, Louise, and Chris Walsh. 2016. A new border pedagogy: Rethinking outbound mobility programs in the Asian century. In Handbook of Research on Study Abroad Programs and Outbound Mobility. Edited by Donna M. Velliaris and Deborah Coleman-George. Hershey: IGI Global, pp. 215-47.

Tracey, Bretag, Robert van der Veen, Sonia Saddiqui, and Ying Zhu. 2016. Critical components in preparing students for short-term study tours to Asia. In Handbook of Research on Study Abroad Programs and Outbound Mobility. Edited by Donna M. Velliaris and Deborah Coleman-George. Hershey: IGI Global, pp. 188-214.

Uzun, Levent. 2012. The Internet and computer-mediated artefacts for foreign language learning and practice, and intercultural communication: MOODLE, second life, and others. Procedia Social and Behavioral Sciences 46: 3296-300. [CrossRef]

Velliaris, Donna M., and Janine M. Pierce. 2017. Cultural diversity: Misconceptions, misinterpretations, and misunderstandings in the classroom. In Intercultural Responsiveness in the Second Language Learning Classroom. Edited by Jones Kathryn and Jason R. Mixon. Hershey: IGI Global, pp. 84-105.

Vickers, Margaret, Florence McCarthy, and Katina Zammit. 2017. Peer mentoring and intercultural understanding: Support for refugee-background and immigrant students beginning university study. International Journal of Intercultural Relations 60: 198-209. [CrossRef]

Yang, Ping. 2011. Developing cross-cultural communication competence through translation. In Proceedings of the "Synergise!" Biennial National Conference of the Australian Institute of Interpreters and Translators: AUSIT 2010. Edited by Annamaria Arnall and Uldis Ozolins. Newcastle Upon Tyne: Cambridge Scholars Publishing, pp. 48-65.

Yang, Ping. 2012. 英汉翻译中的褒贬词语选择 (Complimentary and derogatory wordings in English-Chinese translation). 上海翻译 (Shanghai Journal of Translators) 27: 28-30.

Yang, Ping. 2014. Back to basics: Cracking a nut in using English indefinite articles. English Today 30: 28-33. [CrossRef]

Yang, Ping. 2015a. Intercultural nonverbal communication competence: Meeting body language challenges in facilitating and working with students from culturally diverse backgrounds in the Australian higher education context. In Recent Advances in Language and Communication. Edited by Gerald M. Martinez. New York: Nova Science Publishers, pp. 80-96.

Yang, Ping. 2015b. Reflection on Teaching Principles in Assisting Adult Refugee Learners in Learning English as a Second Language in Australia. Paper presented at the Refugee Education Conference: Celebrating Success, Auckland, New Zealand, October 1-2.

Yang, Ping. 2015c. Developing intercultural competence in TESOL service-learning: Volunteer tutoring for recently-arrived adult refugees in learning English as a second language. In Learning the Language of Global Citizenship: Strengthening Service-Learning in TESOL. Edited by James M. Perren and Adrian J. Wurr. Champaign: Common Ground Publishing, pp. 328-51.

Yang, Ping. 2016. Intercultural communication between East and West: Implications for students on study abroad programs to China. In Handbook of Research on Study Abroad Programs and Outbound Mobility. Edited by Donna M. Velliaris and Deborah Coleman-George. Hershey: IGI Global, pp. 755-77.

Yang, Ping. 2017. Intercultural nonverbal communication competence as intercultural responsiveness in the second language learning classroom. In Intercultural Responsiveness in the Second Language Learning Classroom. Edited by Jones Kathryn and Jason R. Mixon. Hershey: IGI Global, pp. 127-47.

Yang, Ping. 2018a. Developing TESOL teacher intercultural identity: An intercultural communication competence approach. TESOL Journal 9: 525-41. [CrossRef] 
Yang, Ping. 2018b. Experiential learning opportunities: Removing language barriers and maximizing cultural immersion. In Study Abroad Contexts for Enhanced Foreign Language Learning. Edited by Donna M. Velliaris. Hershey: IGI, pp. 189-217.

Yang, Ping. 2018c. Journey to the East: Intercultural adaptation of international students in China. In International Students in China: Education, Student Life and Intercultural Encounters. Edited by Fred Dervin, Xiangyun Du and Anu Härkönen. Cham: Springer International Publishing, pp. 47-75.

Yano, Yasukata. 1998. Linguistic imperialism. Asian Englishes 1: 152-55. [CrossRef]

Zhou, Yuemei. 2004. Comparability study of two national EFL tests (CET-6 and TEM-4) in China. Journal of Asia TEFL 1: 75-100.

(C) 2020 by the author. Licensee MDPI, Basel, Switzerland. This article is an open access article distributed under the terms and conditions of the Creative Commons Attribution (CC BY) license (http://creativecommons.org/licenses/by/4.0/). 